OPTIONAL VACCINE UTILIZATION HAS A MALE GENDER PREFERENCE - A RECORD BASED ANALYSIS FROM A TERTIARY CARE CENTRE OF EASTERN INDIA

Sandeep Kumar Panigrahi ${ }^{1 \#}$, Anumita Maiti ${ }^{2}$, Venkatarao Epari ${ }^{3}$,

${ }^{1}$ Associate Professor, ${ }^{2}$ Ex-Post-graduate, ${ }^{3}$ Professor,

Department of Community Medicine, IMS and SUM Hospital,

Siksha 'O' Anusandhan deemed to be University, Bhubaneswar - 751003.

${ }^{1,2}$ Joint first author

${ }^{\#}$ Corresponding author

Dr. Sandeep Kumar Panigrahi

Associate Professor, Community Medicine Department,

IMS and SUM Hospital, Siksha 'O’ Anusandhan deemed to be University,

Bhubaneswar, Odisha, India - 751003.

Email: dr.sandeepvss@gmail.com; sandeeppanigrahi@hotmail.com 


\section{Conflict of Interest}

None

\section{Source of funding}

None

\section{Acknowledgment}

The authors would like to acknowledge the technical support provided by Dr. Jyotiranjan Sahoo, Assistant Professor, Community Medicine Department of the institute and Dr. Anindita Maiti, Post Graduate, Community Medicine Department, Hi-tech Medical College and Hospital, Bhubaneswar.

\section{Author's note:}

\section{What is already known on this subject}

- Differences in uptake are related to various factors in national immunization program of India.

- Optional vaccines are not a part of the national immunization program,

- There is no clarity regarding pattern and trend of use and gender differences, if any for optional vaccines.

\section{What this study adds}

- Trend of optional vaccine uptake is on the rise reflecting increasing demand among parents.

- Gender differences do not exist for vaccines covered under national immunization program, as seen for Measles vaccine, probably because of universalization.

- Preference for male children exists for most of the optional vaccines (even for $M M R$ ) probably because of the cost involved. 
medRxiv preprint doi: https://doi.org/10.1101/2020.05.17.20072173; this version posted May 20, 2020. The copyright holder for this preprint (which was not certified by peer review) is the author/funder, who has granted medRxiv a license to display the preprint in perpetuity.

$$
\text { It is made available under a CC-BY-ND } 4.0 \text { International license. }
$$

- Gender disparity was absent in Varicella, probably because of fear of parents for scar marks on face of their girl child. 


\title{
OPTIONAL VACCINE UTILIZATION HAS A MALE GENDER PREFERENCE - A RECORD BASED ANALYSIS FROM A TERTIARY CARE CENTRE OF EASTERN INDIA
}

\begin{abstract}
Background And Objectives: Optional vaccines find an important place in immunization today. This study attempts to find out the trend of optional vaccine utilization, over the past three years in the immunization clinic of a tertiary care centre and to find out the association of gender disparity with the utilization of these vaccines.
\end{abstract}

Methods: The retrospective study was conducted during October to December 2016 using the register based secondary data of October 2013 to September 2016. Month wise utilization of optional vaccines (Pneumococcal, influenza, typhoid, varicella, hepatitis A and MMR) and measles was captured. Analysis was done using Stata 12.1 SE.

Results: An increasing trend of utilization was seen for all vaccines including optional vaccines. The mean doses received by male children was significantly more for all optional vaccines (unlike all vaccines taken together) as well as for individual vaccines like Pneumococcal, influenza, typhoid, MMR, hepatitis A ( $<<0.05)$, but not for varicella and measles vaccine $(\mathrm{p}>0.05)$.

Conclusion: Gender disparity (preference for male children) was present for all optional vaccines except varicella, and not in case of measles vaccine used in universal immunization program selected as control.

Keywords: child health; vaccination; gender; immunization; developing country 
medRxiv preprint doi: https://doi.org/10.1101/2020.05.17.20072173; this version posted May 20, 2020. The copyright holder for this preprint

\section{INTRODUCTION}

Immunization is one of the most effective public health strategies for restricting spread of various communicable diseases.(Patnaik, Mishra, and Choudhury 2014) In India, a child dies every minute from vaccine-preventable diseases. It also accounts for almost a fifth of all global under-five deaths; a large number of which are caused by vaccine-preventable diseases such as tuberculosis, pneumonia and diarrhoea.(United Nations Children's Fund (UNICEF) 2016) This is a basic and fundamental preventive service provided free of charge at all public health care facilities in India. The benefits of immunization are not only restricted to improvement in health and life expectancy, but also have social and economic impact at both community and national level. Countries all over the world have their own national immunization program and agenda with an aim to cover some of the common life threatening diseases that can be prevented through these vaccines. Some countries have moved beyond the routine vaccines to vaccines meant to prevent meningococcal meningitis, cervical cancer, etc.

Universal Immunization program (UIP) in India, commonly known as Routine Immunization Program (RIP), aims to universally every mother and child. It currently comprises of the following vaccines: Bacillus Calmette-Guérin (BCG) for prevention of tuberculosis, Oral Polio Vaccine $(O P V)$ and Inactivated Polio Vaccine (IPV) for poliomyelitis, Pentavalent vaccine (consisting of vaccines for prevention of Diphtheria, Pertussis, Tetanus, Hepatitis B and Haemophilus influenzae type b), Measles Rubella (MR) vaccine for Measles and Rubella prevention, Diphtheria Pertussis and Tetanus (DPT) vaccine used as booster, and Tetanus toxoid vaccine used as booster. Rotavirus vaccine for rotavirus associated diarrhoea, Japanese encephalitis (JE) vaccine for Japanese encephalitis and Pneumococcal vaccine for 
medRxiv preprint doi: https://doi.org/10.1101/2020.05.17.20072173; this version posted May 20, 2020. The copyright holder for this preprint

the pneumococcal pneumonia are given in selected states of the country. (Panigrahi and Mahapatro 2015; National Health Portal India 2018)

Vaccination coverage varies considerably from state to state. Differences in uptake are related to various factors like geographical distribution, regional trend, differences between rural and urban, poor and rich, and gender related factors. Complete immunization coverage in urban areas of Odisha was 68 percent and similar to rural Odisha.(Vital Statistics Division and Government of India 2014) Similar were the results when immunization coverage was assessed in an urban city of Odisha (Cuttack had 65 percent coverage) in 2012.(Prusty et al. 2013) This study is an attempt to find out the current trend of optional vaccines use over the past three years in the immunization clinic of a tertiary care centre in India and to find if there is any association of this trend for each vaccine with gender of the beneficiary.

\section{OBJECTIVES}

1. To find out the trend of optional vaccine utilization, that are not covered in the national immunization schedule, over the past three years in the immunization clinic of a tertiary care centre.

2. To find out the association of gender with the observed trend of vaccination.

\section{METHODOLOGY}

The study was a retrospective observational study based on secondary data available from the outpatient register of immunization and child health guidance clinic of the tertiary care centre in eastern part of India. The tertiary care centre is a teaching institute with outpatient turnover of as much as 1000-1200 patients each day. The data collection from registers and records available in the immunization and health guidance clinic was conducted from October to 
medRxiv preprint doi: https://doi.org/10.1101/2020.05.17.20072173; this version posted May 20, 2020. The copyright holder for this preprint

December 2016. The register and records from October 2013 to September 2016 were reviewed and data were collected. The sampling unit was a vaccine dose. Universal sampling method was used, and type of vaccine and gender related data for each vaccine was collected. Name of the vaccine and its type (e.g. PCV-13 is a pneumococcal vaccine, here PCV-13 is the name of the vaccine and pneumococcal vaccine is the type) of individual vaccine and gender of the recipient were considered for each dose. Month wise utilization of doses of vaccines (all vaccines, few optional vaccines and a control vaccine- Measles, given to everyone by government) were included in the data collection sheet. Tally marks were used to compile the data for each of the component variables needed for the study. Data were finally entered into an excel sheet.

Our study included those vaccines where a trend analysis was operationally feasible, and vaccines not facing stock out during this period. Optional vaccines included in the study were Pneumococcal vaccine, Influenza vaccine, Typhoid vaccine, Varicella vaccine, Hepatitis A vaccine and $M M R$ vaccine. Following optional vaccines (with trade names) were included in the study: Pneumococcal vaccines (Prevenar-13, Synflorix); Influenza vaccine (Vaxigrip, Fluarix, Influvac); Typhoid vaccine (Typbar TCV, Typbar); Varicella vaccine (Variped, Varilrix); Hepatitis A (Havrix 720/1440, Avaxim 80, Biovac A); and MMR (Tresivac), as these were brands used in the study setup.

Government vaccine included for the study was Measles vaccine which also acted as a reference vaccine (control) for ensuring follow up of both genders equally post discharge after delivery. Government vaccines given during first 24 hours of birth like BCG, Hepatitis B and OPV were excluded from the study, since this would be dependent on institutional delivery load and will be biased by referral patients (who may not follow up for completing 
all their vaccines). DPT was excluded since it has been merged into pentavalent vaccines in the recent years, while rotavirus vaccine was excluded since it was introduced only in the recent years. Meningococcal Vaccine and Human Papilloma Virus Vaccine (though these are optional vaccines) are rarely used in this clinic and hence were excluded from the current study. Moreover, HPV Vaccine is usually given only to female children, and hence gender disparity cannot be assessed.

Data regarding the number of doses of the vaccine utilization of each month was collected using tally marks. Data was entered in Microsoft Excel Sheet 2016 version and analysed using Stata v 12.1 SE software licensed to one of the authors. Trend analysis plot was done using line graphs and difference in the number of doses by gender for each vaccine was analysed using independent sample t-test. Since the study did not include human subjects, and was record based, the researchers only informed the ethics committee regarding the same as per the mandate of the Institute Ethics Committee (IEC). No ethical approval was taken.

\section{RESULT}

Data of vaccine dose utilization for 36 months (3 consecutive years) were collected from the clinic register. Total number of doses utilized, and that for male and female beneficiaries were noted for all vaccines considered in this study. Out of a total of 10,142 doses of vaccine utilized overall in this period, there were 5,313 (52.4 percent) vaccine doses given to male children and 4,829 (47.6 percent) doses to female. Of all optional vaccine doses given, Pneumococcal vaccine doses were the highest one utilized (19.6 percent) followed by MMR and Typhoid (Table 1). Considering all vaccines, on an average $281.72 \pm 11.74$ dose was utilized in a month with no statistically significant difference between male and female children (male 147.58 \pm 6.74 ; female $134.13 \pm 5.39 ; \mathrm{p}=0.123$ ) (Table 2) 
[Table 1 about here]

[Table 2 about here]

A total number of 5,038 (49.7 percent of all vaccines) optional vaccine doses were utilized during this period, with males receiving 2,956 doses (58.6 percent) and female children receiving 2,082 doses (41.4 percent). Mean number of total optional vaccines given per month was $139.94 \pm 8.12$, for males it was $82.1 \pm 4.6$ doses and for females it was $57.8 \pm 3.7$ doses. The mean number of total optional vaccine doses for males and females were found to be significantly different ( $\mathrm{p}=0.0001,95$ percent $\mathrm{CI}$ : 12.46, 36.09) (Table 2), denoting that male children were receiving more number of optional vaccines in a month as compared to female children.

Among a total of 1,988 Pneumococcal vaccine doses utilized over this period, 1,177 doses were utilized for male and 811 doses for female children. The mean number of Pneumococcal vaccine dose used was $52.22 \pm 4.44$ per month, male receiving $32.69 \pm 2.63$, and female $22.52 \pm 1.92$ doses in a month. It was seen that male children received significantly more number of PCV doses per month than female children during this period ( $\mathrm{p}=0.002,95$ percent CI: 3.65, 16.67) (Table 2). It was also found to be the most common optional vaccine opted for by parents.

Influenza and typhoid vaccine utilization had similar gender distribution. Out of a total of 599 influenza vaccine doses given during this period, 373 were for male and 226 for female children. The mean number doses were more for male as compared to female children (Male $16.63 \pm 1.63 ;$ Female $10.36 \pm 1.01 ; p=0.001,95$ percent CI: $1.58,6.58)$. Among a total of 
medRxiv preprint doi: https://doi.org/10.1101/2020.05.17.20072173; this version posted May 20, 2020. The copyright holder for this preprint

653 typhoid vaccine doses, 420 doses were for male and 233 for female children. The mean number of total typhoid vaccine doses was $18.13 \pm 1.37$ per month, male children receiving $11.66 \pm 0.86$ and female $6.57 \pm 0.58$ doses. This was also found to be significantly more for male children ( $\mathrm{p}=0.000,95$ percent CI: 3.12, 7.26) (Table 2).

The case for varicella vaccine was interesting. A total of 460 doses had been utilized during this period out of which 210 number of doses accounted for male children vaccination in a month and 250 for female children. Here the mean number of total varicella vaccine doses was $12.77 \pm 1.48$ per month, $5.83 \pm 0.69$ for male children and $6.94 \pm 0.86$ for female. This was not found to be significantly different $(\mathrm{p}=0.320,95$ percent CI: $-3.32,1.10)$ (Table 2).

There were 603 hepatitis A vaccine doses utilized during this period. Males had received 360 doses and females had received 243 doses in total. The mean number of doses received a month was $16.75 \pm 0.92$ and was significantly more for males as compared to females (Mean dose $10.0 \pm$ SE 0.66 for male and $6.75 \pm 0.36$ for female, $\mathrm{p}=0.000,95$ percent CI: 1.73 , 4.76) (Table 2).

Measles vaccine, that is provided universally, was taken as the only government vaccine in this study. Males had received 302 and females 272 doses in total, out of 574 doses. The mean number of doses of measles vaccine for male and female children were not found to be statistically different (Male: $8.38 \pm 0.61$ doses/ month; female: $7.55 \pm 0.45$ doses/ month; $\mathrm{p}=$ $0.280,95$ percent CI: $-0.69,2.36$ ) (Table 2). This vaccine acting as a control showed that there was no selection bias in the study, and in the long run there was an equal inflow of patients for both the gender among the study cohort receiving immunization. Comparison between Measles and MMR revealed interesting facts. The mean number of total doses for $M M R$ vaccine was $20.41 \pm 1.11$ per month. Doses for male children were $11.55 \pm 0.69$ in a 
month while for female were $8.66 \pm 0.55$ doses a month, and this difference was found to be statistically significant $(\mathrm{p}=0.003,95$ percent CI: $0.92,11.14)$.

The trend of vaccination was found to be increasing in the immunization clinic of the hospital both in general and for optional vaccines (Fig 1 and 2). Individually all the optional vaccines showed a rising trend, while this was an exception for measles vaccine (Fig 3 to Fig 9). There was a downward trend for the total doses of measles vaccine received over the years (Fig 9), with a reverse trend (upward) for $M M R$ vaccine (Fig 8). Hepatitis $A$ vaccine and $M M R$ showed a mild increasing trend while that for other vaccines was moderate to high, though this has not been quantified. The increasing trend was also evident in case of males and females for all the vaccines combined, as well as for PCV, influenza, typhoid and hepatitis A. Increasing trend was more for females than males for Varicella vaccine, and for $M M R$ vaccine. There was even trend reversal with time in this case, with female children gradually taking up more vaccines as compared to males (Fig 6).

[Fig 1 about here]

[Fig 2 about here]

[Fig 3 about here]

[Fig 4 about here]

[Fig 5 about here]

[Fig 6 about here]

[Fig 7 about here]

[Fig 8 about here]

[Fig 9 about here] 
medRxiv preprint doi: https://doi.org/10.1101/2020.05.17.20072173; this version posted May 20, 2020. The copyright holder for this preprint

\section{DISCUSSION}

Vaccines are estimated to prevent deaths in millions annually, and are of the greatest public health measures as on today. Starting from eradicating smallpox to the verge of eradicating polio and to a good extent measles, vaccination can be thought of as the most cost-effective public health intervention.(Delany, Rappuoli, and De Gregorio 2014)

For ensuring universal immunization coverage of all children below five years and also to eliminate maternal and neonatal tetanus from the country, the government of India is implementing Universal Immunization Program as fixed Routine Immunization(RI) sessions using platforms like Village Health and Nutrition Day(Panigrahi, Mohapatra, and Mishra 2015) or Routine Immunization Days. Vaccination is done using the National Immunization Schedule (NIS)(National Health Portal India 2018) for all children on every Wednesday at a village level. To increase urban immunization coverage (which many a times consists of floating population), National Urban Health Mission (a sub-mission of the National Health Mission, and aims to meet the health care needs of the urban poor, with special reference to the primary health care needs)(National Health Mission, Ministry of Health and Family Welfare, and Government of India 2020) also carries out similar activities. The sessions are usually conducted at the Anganwadi Centre. National Immunization Schedule is followed for the implementation of vaccination under this program. To increase immunization coverage and to reach out every individual, additional activities such as Mission Indradhanush (MI) and Intensified Mission Indradhanush (IMI) (to ensure full immunization coverage more than 90percent and reaching out the outreach areas) are also carried out.(NHP India 2018) Thus the government looks forward to avoid gender discrimination and uniformly vaccinate all children, mothers and adolescents. The effect of gender discrimination in case of vaccines under the national program thus seems to evade. 
medRxiv preprint doi: https://doi.org/10.1101/2020.05.17.20072173; this version posted May 20, 2020. The copyright holder for this preprint

The Indian Academy of Paediatrics (IAP) has also recommended other additional vaccines such as Pneumococcal, typhoid, hepatitis A, influenza, varicella, MMR, meningococcal and $H P V$ as optional vaccines as early as 2014.(Vashishtha et al. 2014) These optional vaccines are not financially supported by the government and they are only available to the individuals for purchase at private clinics or hospitals. Currently optional vaccines are being promoted and parents are being encouraged and counselled by the family practitioners and paediatricians to opt for these vaccines. Studies have shown that awareness among mothers regarding optional vaccines is around 66 percent.(Patnaik, Mishra, and Choudhury 2014). Thus optional vaccines, since not available free of cost, have the potential to show gender disparity, if present, in case of vaccination.

The optional vaccines used in this study were Pneumococcal vaccine, Influenza vaccine, Typhoid vaccine, Varicella vaccine, Hepatitis $A$ vaccine and $M M R$ vaccine. Following optional vaccines (with trade names) were included in the study: Pneumococcal vaccines (Prevenar-13, Synflorix); Influenza vaccine (Vaxigrip, Fluarix, Influvac); Typhoid vaccine (Typbar TCV, Typbar); Varicella vaccine (Variped, Varilrix); Hepatitis A (Havrix 720/1440, Avaxim 80, Biovac A); and $M M R$ (Tresivac), as these were brands used in the study setup.

Pneumococcal vaccine used for the prevention of pneumococcal disease causes by Streptococcus pneumoniae bacteria, is commonly available as a PCV-10 (10-valent) or PCV13 (13-valent) vaccine under the trade name of Synflorix (one dose costing approximately 24 US\$ in India) and Prevenar-13 (one dose costing approximately 51 US\$ in India), respectively. PCV-13 contains serotypes for 1, 3, 4, 5, 6A, 6B, 7F, 9V, 14, 18C, 19A, 19F, and 23F pneumococcal strains. PCV10 contains all serotypes except 3, 6A, and 19A, although there is evidence for some cross-protection for $6 \mathrm{~A}$ and $19 \mathrm{~A}$ related disease. However, there is no potential advantage of using 13 -valent over 10 -valent as indicated in the 
medRxiv preprint doi: https://doi.org/10.1101/2020.05.17.20072173; this version posted May 20, 2020. The copyright holder for this preprint

study.(Temple et al. 2019) Thus, these two were used interchangeable for the current study. Another pneumococcal vaccine PPSV-23 is currently available which is a polysaccharide vaccine and recommended for geriatric population and people who smoke cigarettes or having any lung diseases like Chronic Obstructive Pulmonary Disease (COPD).(Centre for Disease Control and Prevention 2019b) PCV is currently given on pilot basis in certain districts of India in Universal Immunization Program, but is routine recommended as an optional vaccine by Indian Academy of Pediatrics.(Vashishtha et al. 2014; National Health Portal India 2018; National Health Mission 2018)

Influenza vaccine is a contagious disease which causes respiratory illness, and is very common in the west. The influenza season lasts from October to around mid-February (called as flu season). Persons at high risk of influenza include those above 65 years of age, with lung diseases like Asthma, diabetes, heart disease, etc., and even children in the young age. CDC recommends Flu vaccine routine to children once they cross six months of age to be given every year.(Centre for Disease Control and Prevention 2016b) However the recommendations differs in India, as per IAP. It is to be given for high risk category children, which in addition covers children having congenital, acquired or iatrogenic immunodeficiency, asplenia, renal or liver diseases, travellers, etc.(Vashishtha et al. 2014) In our setup, flu vaccine is a routine practice given to all children above six months of age as per CDC guidelines, and then every year. Flu vaccine is available as Vaxigrip (Sanofi India; costing approximately 12 US\$), Fluarix (Glaxo Smith Kline Limited; costing approximately 10 to 14 US\$) and Influvac (Abbott Pharma; costing approximately 13 US\$ in India). Flu vaccine covers usually the commonly circulating strains of both type A and type B influenza. Below 3 years of age, $0.25 \mathrm{ml}$ dose is given and above that $0.5 \mathrm{ml}$ as per posology and indication of the brand.(MIMS 2020; Grohskopf et al. 2016; "Vaccines - Sanofi India" 2019) 
medRxiv preprint doi: https://doi.org/10.1101/2020.05.17.20072173; this version posted May 20, 2020. The copyright holder for this preprint

Typhoid vaccine helps in preventing typhoid fever, which may be life threatening. Earlier a live form (above 6 years and given every 5 years) and an inactivated form (above two years and to be given every two years) was available. Typhoid vaccine is routinely not recommended in US (only to be given for travellers, lab handlers or close contacts of typhoid cases/ carriers) but in India recommended by Indian Academy of Pediatrics in the age group of 9 to 12 months. Usually the conjugate vaccine is in use and available in Indian market.(Vashishtha et al. 2014; US Department of Health and Human Services and CDC 2019) It is available as Typbar TCV (Bharat Biotech; costing approximately 24 US\$ in India), and it a vaccine containing Salmonella typhi Ty2 polysaccharide. Tetanus Toxoid is used as a conjugate and helps in a lasting immunity even without booster doses (single dose eliciting seroconversion in 98.05 percent).(Bharat Biotech 2019) Typhoid conjugate vaccine is given by intramuscular route after two years of age (now can be given in less than 2 years also) with a dose of $0.5 \mathrm{ml}$.

Varicella Zoster vaccine $(\mathrm{VZV})$ is a vaccine for prevention of the very contagious disease called Chicken-pox which causes blisters with itching, fever and tiredness. Vaccine available for the same have been reviewed by World Health Organization for its effectiveness and concluded that even with a single dose given to protect children of 9 months to 12 years against all grades of severity of varicella disease, an approximate mean vaccine efficacy was 80 percent against all grades of disease severity, irrespective of vaccine type. Two doses of the vaccine whereas was said to be effective in about 90 percent of cases for preventing chicken pox. VZV is available in India as Varilrix (Glaxo Smith Kline Limited; costing approximately 16 US\$ in India) and Variped (Merck Sharp and Dohme Corporation India; costing approximately 19 US\$ in India), most commonly. They are given $0.5 \mathrm{ml}$ by sub- 
medRxiv preprint doi: https://doi.org/10.1101/2020.05.17.20072173; this version posted May 20, 2020. The copyright holder for this preprint

cutaneous route. (Centre for Disease Control and Prevention 2016a; Strategic Advisory Group of Experts on Immunization 2014)

Hepatitis A is a form of hepatitis caused by the hepatitis A virus (HAV), which can affect anyone. Hepatitis A vaccine is effective for the long-term prevention of HAV infection and can be given to persons one year of age and older. Hepatitis is transmitted through feco-oral route and India has seen outbreaks related mostly to Hepatitis A or Hepatitis E, at various points of time.(Paul et al. 2015; Kumar et al. 2015; Rakesh et al. 2014) This may be also the reason why IAP recommends vaccination of children with Hepatitis A vaccine from one year of age.(Vashishtha et al. 2014) Hepatitis A vaccine is available in India as Havrix junior 720 (Glaxo Smith Kline Biologicals; approximate cost is 15 US\$) or Avaxim 80 (Sanofi India Limited; approximate cost is 18 US\$) and is given in children as two doses of $0.5 \mathrm{ml}$ each 6 months apart by intramuscular route. Alternate to this inactivated vaccine is a single dose of live vaccine available as Biovac A (Wochardt Limited; approximate cost of one dose is 17 US\$) given subcutaneously as $0.5 \mathrm{ml}$. All have a good seroconversion rate of more than 95 percent if given as per schedule. (Bhave et al. 2015; Abarca et al. 2008)

Measles, Mumps and Rubella are viral contagious diseases. Measles is caused by Measles virus, and causes fever with rash along with cough, runny nose, and red, watery eyes. Diarrhoea is a usual complications along with pneumonia, and death. Mumps is caused by mumps virus and leads to inflammation of salivary glands (mainly parotid). It is accompanied by fever, headache, muscle aches, tiredness and loss of appetite. Encephalitis/meningitis may be a complication. Rubella (also known as German Measles) causes fever, sore throat, rash, headache, and red, itchy eyes. If infected during pregnancy it may lead to a miscarriage or baby born with serious birth defects. Hence children 12 through 15 months of age are to be vaccinated with $0.5 \mathrm{ml}$ subcutaneous dose, with a booster dose at 5 to 6 years of age. (Centre for Disease Control and Prevention 2019c, 2019a) MMR is a live attenuated vaccine, and is 
medRxiv preprint doi: https://doi.org/10.1101/2020.05.17.20072173; this version posted May 20, 2020. The copyright holder for this preprint

very economic to be afforded by individuals in the developing countries. In India it is marketed as Tresivac (Serum Institute India Pvt. Ltd.; cost for one dose approximately 1 US\$).(Serum Institute of India Pvt. Ltd. 2019)

Pneumococcal vaccine was the most common optional vaccine (highest number of doses) used by parents as per this study. The reason may be because it was given on multiple occasions as $3+1$ or $2+1$ schedule for an under five child. From this study, we found that there was an increasing trend in all vaccines. Optional vaccines taken overall and individually (Pneumococcal vaccine, Influenza vaccine, Typhoid vaccine, Varicella vaccine, Hepatitis A vaccine and $M M R$ vaccine) showed a strong increasing trend, with mild increasing trend seen only for Hepatitis A vaccine. Measles vaccine showed a decreasing trend. This increasing trend could be due to increasing awareness and acceptability of parents for optional vaccines. There was gender disparity (preference for male children) observed for all the optional vaccines except varicella vaccine among optional vaccines and measles vaccine among vaccines supplied under Universal immunization program (UIP).

A study done by Padda et al. in the community setting in other parts of India has also shown that the coverage of optional vaccines was significantly more for males as compared to females (53.9 percent for male vs 46.1 percent for female).(Padda et al. 2012) A study done for the analysis of factors responsible for uptake of rotavirus vaccine in a paediatric clinic also showed association of gender of the baby with opting for optional vaccines. Other factors associated were mother's age and occupation, the mode of payment, the number of previous visits and counselling sessions and the pre-counselling awareness or knowledge were significantly associated with uptake of vaccine.(Kutty et al. 2010)

For every optional vaccine that were meant to purchase by the parent, preference was given to male children over female excepting for varicella (chicken pox) vaccine. Vaccines that 
medRxiv preprint doi: https://doi.org/10.1101/2020.05.17.20072173; this version posted May 20, 2020. The copyright holder for this preprint

were provided free of cost by the government under immunization program had no gender difference in vaccine utilization (evident from comparison of gender disparity for measles vaccine as control). For $M M R$ vaccine gender disparity was present in favour of male children, even though the cost of this vaccine was reasonably low in comparison, and even when it was of public health importance in countries like India when given to female children.

Varicella vaccine was found to be an exception where there was no difference in vaccine dose utilization between male and female children. This may be probably due to social stigma for delay in marriage of their girl child due to scar marks on face and elsewhere arising out of chicken pox, but has not been ascertained in this study.

Finally, there was no single optional vaccine in our study that was provided more to female as compared to male children. Further qualitative research might be needed to find out the reasons behind this disparity that are amenable to corrections. By doing qualitative research probably we will get to know many themes(Angelillo et al. 1999; Patnaik, Mishra, and Choudhury 2014) like lack of knowledge of parents about the importance of vaccination for female children; importance of various socio-demographic factors leading to gender disparity; education of the decision maker in the family for financial aspects (usually father); target for health education (father/ mother/ both); or approaches in communication for health education.

The study could have been biased by the bias in counselling technique of the physicians in the immunization and health guidance clinic, but this was avoided by certain principles. One, there was uniform displays of information, education and communication materials. Second, there was a strict protocol from entry of the beneficiary to the exit of the beneficiary and every physician joining the institute was trained and made versed with the protocol before 
medRxiv preprint doi: https://doi.org/10.1101/2020.05.17.20072173; this version posted May 20, 2020. The copyright holder for this preprint

getting posted. Third, there was an independent counselling corner for resolving every small query of the client. The next bias could have been marked differences in pricing of the optional vaccines. But as mentioned earlier, the pricing difference was very minimal except for the brands of pneumococcal vaccine (10-valent costing quite less than 13-valent PCV). However, the beneficiaries were given choices to select even PVC-10 over PCV-13 in case of having financial constraints. Analysis was done merging both as PCV and not independently, thus avoiding bias during analysis.

Gender inequality has been a tradition in Indian culture. Female feticide is trend reported in Asian countries, and prevalence to a large extent in many regions of India, especially in northern India where the child sex ratio drops to less than 850 over the country average of 914 as per Census 2011.(Ahmad and Darussalam 2010; Office of the Registrar General of India 2011a) A higher proportion of under five female children with birth order two or more, and belonging to anganwadis of urban slums of Maharashtra (India), were found to be malnourished compared to the male children.(Patel et al. 2013) The national difference in the male to female literacy rate still stands at 16.68 points (male 82.14 percent, female 65.46 percent), though has been reduced than the previous Census in 2001. The difference is marked in cases of Empowered Action Group States (EAG), which contribute to high burden of disease in the country.(Office of the Registrar General of India 2011b) Moreover there has been an Indian Psychology attached at every stage of life in India, existing not only in the rural and uneducated population of the country, but also in other sections also. Adolescent girls in the country are imparted less knowledge on sex education, making sometimes menstrual hygiene also difficult to maintain. Early school drop out followed by early marriage, and early child bearing is a custom very common in rural India. Ignorance of legal rights by a girl also leads to issues like exposure to domestic violence, economic dependence, 
medRxiv preprint doi: https://doi.org/10.1101/2020.05.17.20072173; this version posted May 20, 2020. The copyright holder for this preprint

low self-esteem, no rights on property, denial of decision making rights, child immoral trafficking and exposure to sexually transmitted diseases, etc.(Rao, Vidya, and Sriramya 2015)

Continuous efforts have been taken up by the Indian government to demolish this discrimination for female supported by global developmental partners. Pre-conceptional and pre-natal diagnostic (PC-PNDT) act 1994 (amended in 2011) prohibits on sex determination at the time of delivery and even during conception (during artificial insemination).(Bhaktwani 2012) Inclusion of education on sexual and reproductive health as a part of Reproductive Maternal Neonatal Child Health Plus Adolescent since 2014 (RMNCHA Strategy) where Rashtriya Kishor Swasthya Karyakram (RKSK) is rolled out for adolescents.(National Health Mission 2020) Similarly, universalization of immunization ensures that a girl child even gets vaccinated for the common vaccine preventable diseases. Laws have been imposed to restrict teenage marriage and pregnancy. Girl education has also been prioritized through initiatives like Beti Bachao Beti Padhao Scheme by the Ministry of Women and Child Development.(Ministry of WCD Government of India 2017) Apart from this, government has taken many steps to remove the gender bias towards a girl child, like reservation of seats in technical education, legislative assemblies of parliament, government jobs, etc.(Rao, Vidya, and Sriramya 2015)

However, in spite of all the measures taken up by the government, this study revealed an interesting untouched area regarding differences in use of optional vaccines, which points towards the still existing gender differences. This can be considered as a proxy indicator in the assessment of gender differences alongside with other indicators taken in Census or other surveys. Gender Inequality Index (GII) is commonly used for measuring gender differences, 
medRxiv preprint doi: https://doi.org/10.1101/2020.05.17.20072173; this version posted May 20, 2020. The copyright holder for this preprint

and hovers around three key components like health, empowerment and labour market, based on which female gender index and male gender index are calculated.(United Nation Development Programme 2019) But considering a small geographical area or a state/ county, an indicator like this - use of optional vaccines among the population - can show the gender differences still existing in the field of health, more related to attitude of the population.

Organizations like the Global Alliance for Vaccine Initiative (GAVI)(WHO 2016), also exert substantial pressure on developing countries to incorporate these optional vaccines into their immunization schedule. Recently there are pilot projects ongoing for introduction of Pneumococcal conjugate vaccine (PCV), Measles Mumps and Rubella (MMR) trivalent vaccine and even Japanese-B Encephalitis (JE) vaccine.(Paul and Sahoo 2015; Mishra and Mishra 2008) Injectable Polio Vaccine (IPV) has also been incorporated in the schedule and given at cold chain points as fractional dose of IPV given intradermal at 6 and 14 weeks, though initially planned for a single dose at 14 weeks.(World Health Organization 2019; Indian Academy of Pediatrics (IAP) Advisory Committee on Vaccines and Immunization Practices (ACVIP) et al. 2016) But at every point of time, there will be additional vaccines made available in the market, which are not in the immunization program of the country, which can act as proxy indicator to point at the health related gender discrimination in the community.

\section{CONCLUSION}

From this study, we concluded that there was an observable increasing trend in vaccination at this tertiary care facility. Gender disparity was probably present in all the optional vaccines except for varicella vaccine. A well-designed cohort study may throw more light on this 
issue. More robust counselling may be needed whenever there is a girl child which may contribute to reduced gender disparity.

\section{LIMITATION}

1. This is a record based study, hence there may not be strong level of evidence.

2. Most of the sociodemographic characteristics of parents were not captured, which were beyond the capacity of the researchers.

3. Doses of vaccine have been considered and not children as cohort. Thus, different children might have received the doses.

4. The findings are limited to a tertiary care facility, and may need interpretation with care when considered for generalizing.

5. Counselling technique of the clinicians have not been taken into consideration, which might influence the uptake of optional vaccines thus leading to gender disparity.

\section{REFERENCES}

Abarca, Katia, Isabel Ibánez, Cecilia Perret, Pablo Vial, and Jean Antoine Zinsou. 2008.

"Immunogenicity, Safety, and Interchangeability of Two Inactivated Hepatitis A Vaccines in Chilean Children.” International Journal of Infectious Diseases 12 (3): 27077. https://doi.org/10.1016/j.ijid.2007.08.006.

Ahmad, Nehaluddin, and Brunei Darussalam. 2010. "Female Feticide in India." Issues in Law and Medicine 26 (1): 13-29. https://doi.org/10.5005/jp/books/12328_41.

Angelillo, I. F., G. Ricciardi, P. Rossi, P. Pantisano, E. Langiano, and M. Pavia. 1999.

"Mothers and Vaccination: Knowledge, Attitudes, and Behaviour in Italy." Bulletin of the World Health Organization 77 (3): 224-29. 
medRxiv preprint doi: https://doi.org/10.1101/2020.05.17.20072173; this version posted May 20, 2020. The copyright holder for this preprint (which was not certified by peer review) is the author/funder, who has granted medRxiv a license to display the preprint in perpetuity.

It is made available under a CC-BY-ND 4.0 International license .

Bhaktwani, Anita. 2012. “The PC-PNDT Act in a Nutshell.” Indian Journal of Radiology and Imaging. Wolters Kluwer -- Medknow Publications. https://doi.org/10.4103/09713026.101114.

Bharat Biotech. 2019. "TypbarTCV|Typhoid Vaccine in India|Vaccine for Typhoid-Bharat Biotech.” 2019. https://www.bharatbiotech.com/typbartcv.html.

Bhave, Sheila, Amita Sapru, Ashish Bavdekar, Vaibhavi Kapatkar, and Amey Mane. 2015. "Long-Term Immunogenicity of Single Dose of Live Attenuated Hepatitis A Vaccine in Indian Children.” Indian Pediatrics 52 (8): 687-90. https://doi.org/10.1007/s13312-0150697-8.

Centre for Disease Control and Prevention. 2016a. "Chickenpox (Varicella) Vaccination |

CDC." Centre for Disease Control and Prevention. November 22, 2016.

https://www.cdc.gov/vaccines/vpd/varicella/index.html.

—_. 2016b. "Seasonal Influenza (Flu) Vaccination and Preventable Disease." Centre for Disease Control and Prevention. November 22, 2016.

https://www.cdc.gov/vaccines/vpd/flu/index.html. . 2019a. "MMR Vaccination | What You Should Know | Measles, Mumps, Rubella |

CDC." Centers for Disease Control and Prevention. 2019.

https://www.cdc.gov/vaccines/vpd/mmr/public/index.html.

—_. 2019b. "Pneumococcal Vaccination | CDC." Centre for Disease Control and

Prevention. 2019. https://www.cdc.gov/vaccines/vpd/pneumo/index.html.

—_. 2019c. "Safety Information for Measles, Mumps, Rubella (MMR) Vaccine | CDC."

Centers for Disease Control and Prevention. 2019.

https://www.cdc.gov/vaccinesafety/vaccines/mmr-vaccine.html.

Delany, Isabel, Rino Rappuoli, and Ennio De Gregorio. 2014. "Vaccines for the 21st

Century.” EMBO Molecular Medicine. Blackwell Publishing Ltd. 
medRxiv preprint doi: https://doi.org/10.1101/2020.05.17.20072173; this version posted May 20, 2020. The copyright holder for this preprint

https://doi.org/10.1002/emmm.201403876.

Grohskopf, Lisa A., Leslie Z. Sokolow, Karen R. Broder, Sonja J. Olsen, Ruth A. Karron,

Daniel B. Jernigan, and Joseph S. Bresee. 2016. "Prevention and Control of Seasonal

Influenza with Vaccines Recommendations of the Advisory Committee on

Immunization Practices - United States, 2016-17 Influenza Season.” MMWR

Recommendations and Reports 65 (5): 1-52. https://doi.org/10.15585/mmwr.rr6703a1.

Indian Academy of Pediatrics (IAP) Advisory Committee on Vaccines and Immunization

Practices (ACVIP), Vipin M Vashishtha, Jaydeep Choudhary, Sangeeta Yadav, Jeeson C

Unni, Pramod Jog, Sachidanand S Kamath, et al. 2016. "Introduction of Inactivated

Poliovirus Vaccine in National Immunization Program and Polio Endgame Strategy.”

Indian Pediatrics 53 Suppl 1 (15): S65-69.

http://www.ncbi.nlm.nih.gov/pubmed/27133231.

Kumar, Tripurari, Aakash Shrivastava, Anil Kumar, Kayla F. Laserson, Jai P. Narain,

Srinivasaraghavan Venkatesh, Lakhbir S. Chauhan, and Francisco Averhoff. 2015.

“Viral Hepatitis Surveillance — India, 2011-2013.” Morbidity and Mortality Weekly

Report 64 (28): 758-62. https://doi.org/10.15585/mmwr.mm6428a3.

Kutty, P Kannan, Mrcp Paediatrics, G Pathmanathan Mphil Microbiology, and N M Salleh

Drph Tulane. 2010. "Analysis of Factors in Response to Rotavirus Vaccination."

Medical Journal of Malaysia 65 (2).

MIMS. 2020. "Vaxigrip Full Prescribing Information, Dosage \& Side Effects | MIMS.Com.” https://www.mims.com/philippines/drug/info/vaxigrip/?type=full.

Ministry of WCD Government of India. 2017. "Beti Bachao Beti Padhao | Ministry of

Women \& Child Development | GoI.” 2017. https://wcd.nic.in/bbbp-schemes.

Mishra, Anamika, and Rakesh Mishra. 2008. "Universal Pneumococcal Vaccination in India:

Is It a Priority?" Indian Pediatrics 45 (2): 161-62. 
National Health Mission. 2018. "National Immunization Schedule."

https://nhm.gov.in/New_Updates_2018/NHM_Components/Immunization/report/Nation

al_Immunization_Schedule.pdf.

——. 2020. “Adolescent Health (RKSK) $\square::$ National Health Mission.” 2020.

https://nhm.gov.in/index1.php?lang=1\&level=2\&sublinkid=818\&lid=221.

National Health Mission, Ministry of Health and Family Welfare, and Government of India.

2020. “National Urban Health Mission $\square::$ National Health Mission.” 2020.

https://nhm.gov.in/index1.php?lang=1\&level=1\&sublinkid=970\&lid=137.

National Health Portal India. 2018. "Universal Immunisation Programme | National Health

Portal Of India.” 2018. https://www.nhp.gov.in/universal-immunisation-programme_pg.

NHP India. 2018. “Mission Indradhanush | National Health Portal Of India.” 2018.

https://www.nhp.gov.in/mission-indradhanush1_pg.

Office of the Registrar General of India. 2011a. "Gender Composition of the Population-

Census 2011.” Census 2011 Report. 2011. http://censusindia.gov.in/2011-prov-

results/data_files/india/Final_PPT_2011_chapter5.pdf.

—_. 2011b. "State of Literacy in India." Census 2011 Report. 2011.

http://censusindia.gov.in/2011-prov-

results/data_files/india/Final_PPT_2011_chapter6.pdf.

Padda, Preeti, Harpreet Kaur, Amanpreet Kaur, Harpreet Kaur, and Kanwardeep Jhajj. 2012.

"Immunization Coverage of Optional Vaccines." Online Journal of Health and Allied

Sciences 11 (2).

Panigrahi, S K, and S Mahapatro. 2015. "Open Vial Policy in India--A Commentary.”

Vaccine 33 (8): 943.

Panigrahi, S K, B Mohapatra, and K Mishra. 2015. “Awareness, Perception and Practice of

Stakeholders in India Regarding Village Health and Nutrition Day." Journal of Family 
medRxiv preprint doi: https://doi.org/10.1101/2020.05.17.20072173; this version posted May 20, 2020. The copyright holder for this preprint (which was not certified by peer review) is the author/funder, who has granted medRxiv a license to display the preprint in perpetuity.

It is made available under a CC-BY-ND 4.0 International license.

Medicine and Primary Care 4 (2): 244.

Patel, Kriti A., Sanjivani D. Langare, J. D. Naik, and S. S. Rajderkar. 2013. “Gender

Inequality and Bio-Social Factors in Nutritional Status among under Five Children

Attending Anganwadis in an Urban Slum of a Town in Western Maharashtra, India.”

Journal of Research in Medical Sciences 18 (4): 341-45.

Patnaik, A, R N Mishra, and K Choudhury. 2014. "Effect of Maternal Education on Adoption of Immunization Services-a Case Control Study in Bhubaneswar, Odisha.” Indian

Journal of Public Health Research and Development 5 (3): 231-33.

https://doi.org/10.5958/0976-5506.2014.00309.X.

Paul, Sourabh, PreetamB Mahajan, Vikas Bhatia, JyotiRanjan Sahoo, and DillipKumar

Hembram. 2015. "Investigation of Jaundice Outbreak in a Rural Area of Odisha, India:

Lessons Learned and the Way Forward." Community Acquired Infection 2 (4): 131.

https://doi.org/10.4103/2225-6482.172650.

Paul, Sourabh, and Jyotiranjan Sahoo. 2015. "Four New Vaccines for Routine Immunization in India: What about Hemophilus Influenza B and Pneumococcal Vaccine?" Journal of Family Medicine and Primary Care 4 (1): 9-12. https://doi.org/10.4103/22494863.152238 .

Prusty, Santosh K., Bhuputra Panda, Abhimanyu S. Chauhan, and Jayanta K. Das. 2013.

"Factors Affecting Immunization Coverage in Urban Slums of Odisha, India:

Implications on Urban Health Policy." Healthcare in Low-Resource Settings 1 (2): 18. https://doi.org/10.4081/hls.2013.e18.

Rakesh, P. S., Daniel Sherin, Hari Sankar, Marydasan Shaji, Saraswathy Subhagan, and Sreekumar Salila. 2014. "Investigating a Community-Wide Outbreak of Hepatitis A in India.” Journal of Global Infectious Diseases 6 (2): 59-64.

https://doi.org/10.4103/0974-777X.132040. 
Rao, G. Prasad, K. L. Vidya, and V. Sriramya. 2015. “The Indian 'Girl’ Psychology: A Perspective.” Indian Journal of Psychiatry. Medknow Publications. https://doi.org/10.4103/0019-5545.161480.

Serum Institute of India Pvt. Ltd. 2019. “Tresivac - Measles, Mumps and Rubella Vaccine (Live) I.P. (Freeze-Dried).” 2019. https://www.seruminstitute.com/product_ind_tresivac.php.

Strategic Advisory Group of Experts on Immunization. 2014. "Background Paper on Varicella Vaccine SAGE Working Group on Varicella and Herpes Zoster Vaccines Contents." World Health Organisation (WHO), 1-54.

Temple, Beth, Nguyen Trong Toan, Vo Thi Trang Dai, Kathryn Bright, Paul Vincent Licciardi, Rachel Ann Marimla, Cattram Duong Nguyen, et al. 2019. “Immunogenicity and Reactogenicity of Ten-Valent versus 13-Valent Pneumococcal Conjugate Vaccines among Infants in Ho Chi Minh City, Vietnam: A Randomised Controlled Trial.” The Lancet Infectious Diseases 19 (5): 497-509. https://doi.org/10.1016/S14733099(18)30734-5.

United Nation Development Programme. 2019. “Gender Inequality Index (GII).” Human Development Reports. 2019. http://hdr.undp.org/en/content/gender-inequality-index-gii. United Nations Children's Fund (UNICEF). 2016. “UNICEF - Immunization - Why Are Children Dying?" 2016.

US Department of Health and Human Services, and CDC. 2019. "Vaccine Information Statement: Typhoid Vaccines - What You Need to Know.” www.vaers.hhs.gov.

“Vaccines - Sanofi India.” 2019. 2019. https://www.sanofi.in/en/science-andinnovation/vaccine-products.

Vashishtha, Vipin M., Panna Choudhury, Ajay Kalra, Anuradha Bose, Naveen Thacker, Vijay N. Yewale, C. P. Bansal, and Pravin J. Mehta. 2014. "Indian Academy of 
Pediatrics (IAP) Recommended Immunization Schedule for Children Aged 0 through 18 Years — India, 2014 and Updates on Immunization.” Indian Pediatrics 51 (10): 785800. https://doi.org/10.1007/s13312-014-0504-y.

Vital Statistics Division, and Government of India. 2014. “ANNUAL HEALTH SURVEY

(AHS) Second Updation Bulletin 2012-13."

WHO. 2016. "WHO | Global Alliance for Vaccines and Immunization (GAVI)."

Http://Www.Who.Int/Mediacentre/Factsheets/Fs169/En/. World Health Organization. 2016.

https://doi.org/http://www.unicef.org/supply/files/PCV_Supply_Status_2013February_U NICEF_SD_Final.pdf.

World Health Organization. 2019. "WHO | Fractional Dose IPV.” WHO. World Health Organization. 2019.

https://www.who.int/immunization/diseases/poliomyelitis/endgame_objective2/inactivat ed_polio_vaccine/fractional_dose/en/. 
medRxiv preprint doi: https://doi.org/10.1101/2020.05.17.20072173; this version posted May 20, 2020. The copyright holder for this preprint (which was not certified by peer review) is the author/funder, who has granted medRxiv a license to display the preprint in perpetuity.

It is made available under a CC-BY-ND 4.0 International license .

Table 1: Number of optional vaccine doses as per type and their proportion $(\mathbf{n = 1 0 , 1 4 2 )}$

\begin{tabular}{|c|c|c|c|}
\hline SI Type of Vaccine & $\operatorname{Number}(\%)^{\wedge}$ & Male (\%) & Female (\%) \\
\hline 1. Pneumococcal & $1,988(19.6)$ & $1,177(59.2)$ & $811(40.8)$ \\
\hline 2. Influenza & $599(5.9)$ & $373(62.3)$ & $226(37.7)$ \\
\hline 3. Typhoid & $653(6.4)$ & $420(64.3)$ & $233(35.7)$ \\
\hline 4. Varicella & $460(4.5)$ & $210(45.7)$ & $250(54.3)$ \\
\hline 5. Hepatitis-A & 603 (5.9) & $360(59.7)$ & $243(40.3)$ \\
\hline 6. $\mathrm{MMR}$ & $735(7.3)$ & $416(56.6)$ & $319(43.4)$ \\
\hline All optional vaccines & $5038(49.7)$ & $2956(29.2)$ & $2082(20.5)$ \\
\hline 7. Measles & $574(5.7)$ & $302(52.6)$ & $272(47.4)$ \\
\hline Total doses & $5612(55.3)$ & $3258(32.1)$ & $2354(23.2)$ \\
\hline \multicolumn{4}{|c|}{ Percentage is calculated from total number of doses for all vaccines i.e. 10,142 (excluding a } \\
\hline
\end{tabular}

Table 2: Mean doses of each vaccine (total, and gender wise) received over last three years

\begin{tabular}{|c|c|c|c|c|c|}
\hline SI & Vaccine & $\begin{array}{l}\text { Mean } \pm \mathrm{SE} \\
\text { (Total doses) }\end{array}$ & $\begin{array}{l}\text { Mean } \pm \text { SE doses } \\
\text { (Male) }\end{array}$ & $\begin{array}{l}\text { Mean } \pm \text { SE doses } \\
\text { (Female) }\end{array}$ & $P$ value $(95 \% \mathrm{CI})$ \\
\hline 1. & All Vaccines & $281.72 \pm 11.74$ & $147.58 \pm 58$ & $134.13 \pm 5.39$ & $0.123(-3.77,30.66)$ \\
\hline 2. & All Optional Vaccines & $139.94 \pm 8.12$ & $82.11 \pm 4.64$ & $57.83 \pm 3.68$ & $0.000(12.46,36.09)$ \\
\hline 3. & Pneumococcal Vaccine & $55.22 \pm 4.43$ & $32.69 \pm 2.63$ & $22.52 \pm 1.92$ & $0.002(3.65,16.67)$ \\
\hline 4. & Influenza Vaccine & $16.63 \pm 1.63$ & $10.36 \pm 1.01$ & $6.27 \pm 0.73$ & $0.001(1.58,6.58)$ \\
\hline 5. & Typhoid Vaccine & $18.13 \pm 1.37$ & $11.66 \pm 0.86$ & $6.47 \pm 0.58$ & $0.000(3.12,7.26)$ \\
\hline 6. & Varicella Vaccine & $12.77 \pm 1.48$ & $5.83 \pm 0.69$ & $6.94 \pm 0.86$ & $0.320(-3.32,1.10)$ \\
\hline 7. & Hepatitis-A Vaccine & $16.75 \pm 0.92$ & $10.00 \pm 0.66$ & $6.75 \pm 0.36$ & $0.000(1.73,4.76)$ \\
\hline 8. & MMR Vaccine & $20.41 \pm 1.11$ & $11.55 \pm 0.69$ & $8.86 \pm 0.55$ & $0.003(0.92,11.14)$ \\
\hline & Measles Vaccine & $16.08 \pm 1.00$ & $8.38 \pm 0.61$ & $7.55 \pm 0.45$ & $0.280(-0.69,2.36)$ \\
\hline
\end{tabular}


medRxiv preprint doi: https://doi.org/10.1101/2020.05.17.20072173; this version posted May 20, 2020. The copyright holder for this preprint (which was not certified by peer review) is the author/funder, who has granted medRxiv a license to display the preprint in perpetuity.

$$
\text { It is made available under a CC-BY-ND } 4.0 \text { International license. }
$$


medRxiv preprint doi: https://doi.org/10.1101/2020.05.17.20072173; this version posted May 20, 2020. The copyright holder for this preprint (which was not certified by peer review) is the author/funder, who has granted medRxiv a license to display the preprint in perpetuity.

It is made available under a CC-BY-ND 4.0 International license .

Fig 1: Trend of all vaccines utilized at the clinic from 2013 to 2016

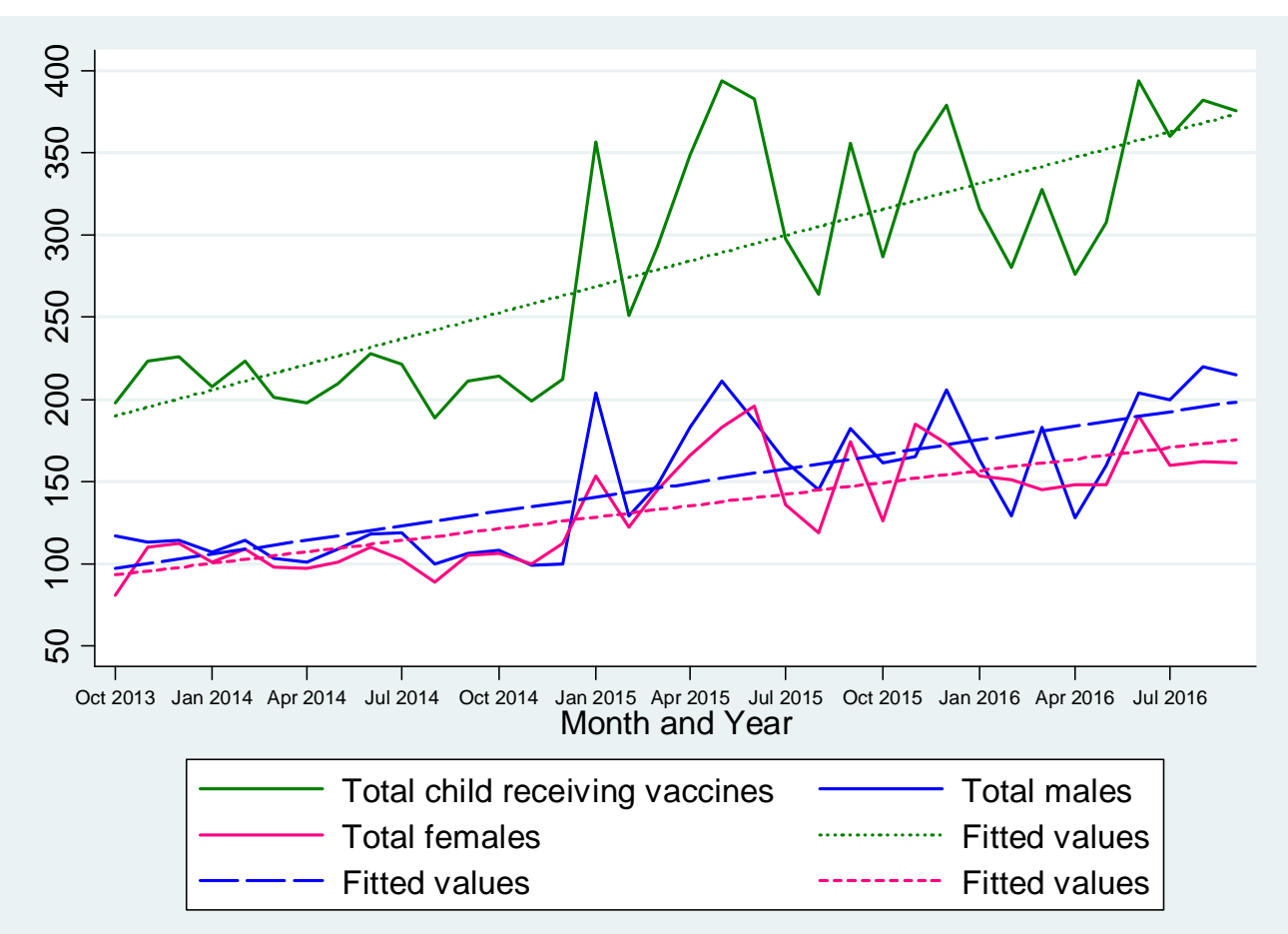

Fig 2: Trend of optional vaccines utilized at the clinic from 2013 to 2016

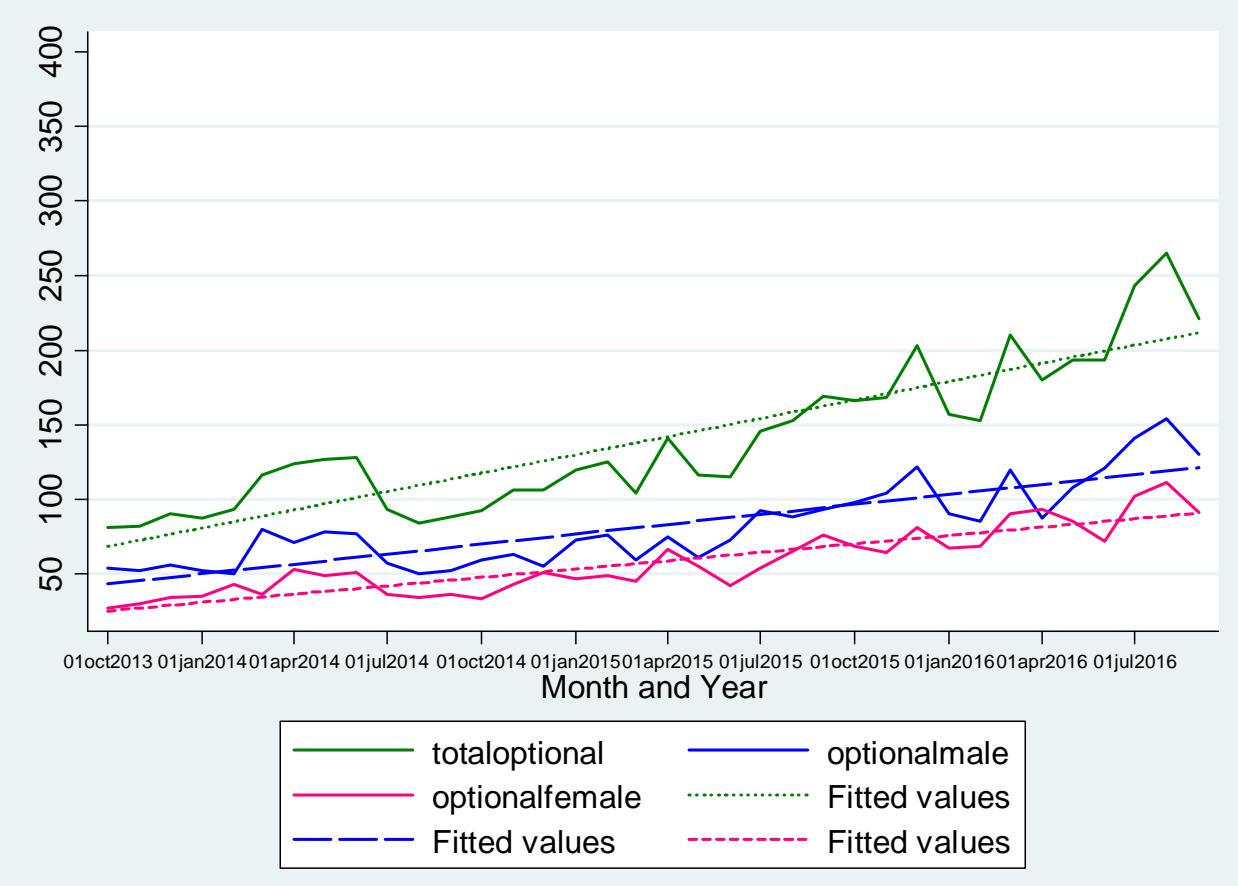


medRxiv preprint doi: https://doi.org/10.1101/2020.05.17.20072173; this version posted May 20, 2020. The copyright holder for this preprint (which was not certified by peer review) is the author/funder, who has granted medRxiv a license to display the preprint in perpetuity.

It is made available under a CC-BY-ND 4.0 International license .

Fig 3: Trend of Pneumococcal vaccines utilized at the clinic from 2013 to 2016

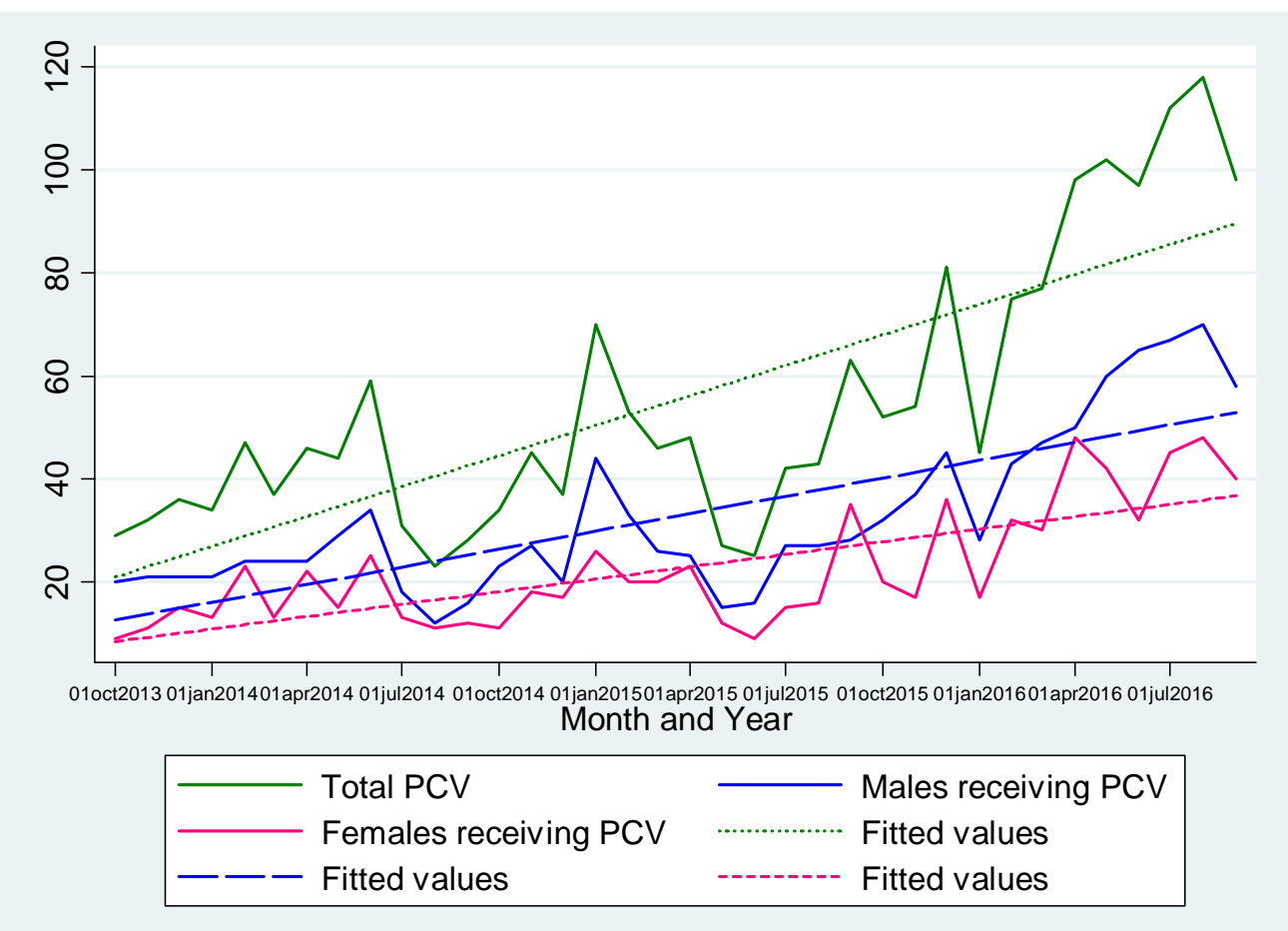

Fig 4: Trend of influenza vaccines utilized at the clinic from 2013 to 2016

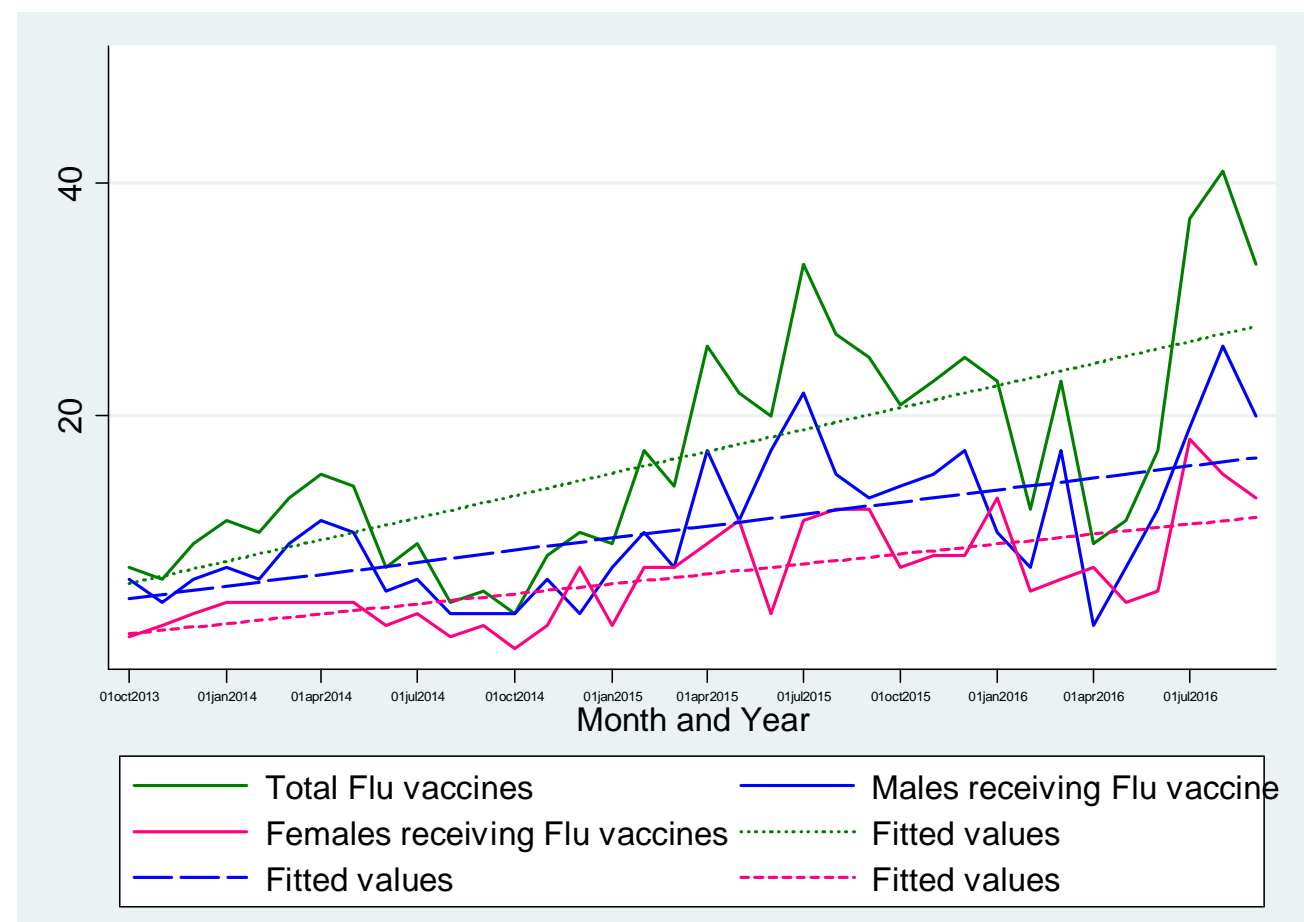


medRxiv preprint doi: https://doi.org/10.1101/2020.05.17.20072173; this version posted May 20, 2020. The copyright holder for this preprint (which was not certified by peer review) is the author/funder, who has granted medRxiv a license to display the preprint in perpetuity. It is made available under a CC-BY-ND 4.0 International license .

Fig 5: Trend of typhoid vaccines utilized at the clinic from 2013 to 2016

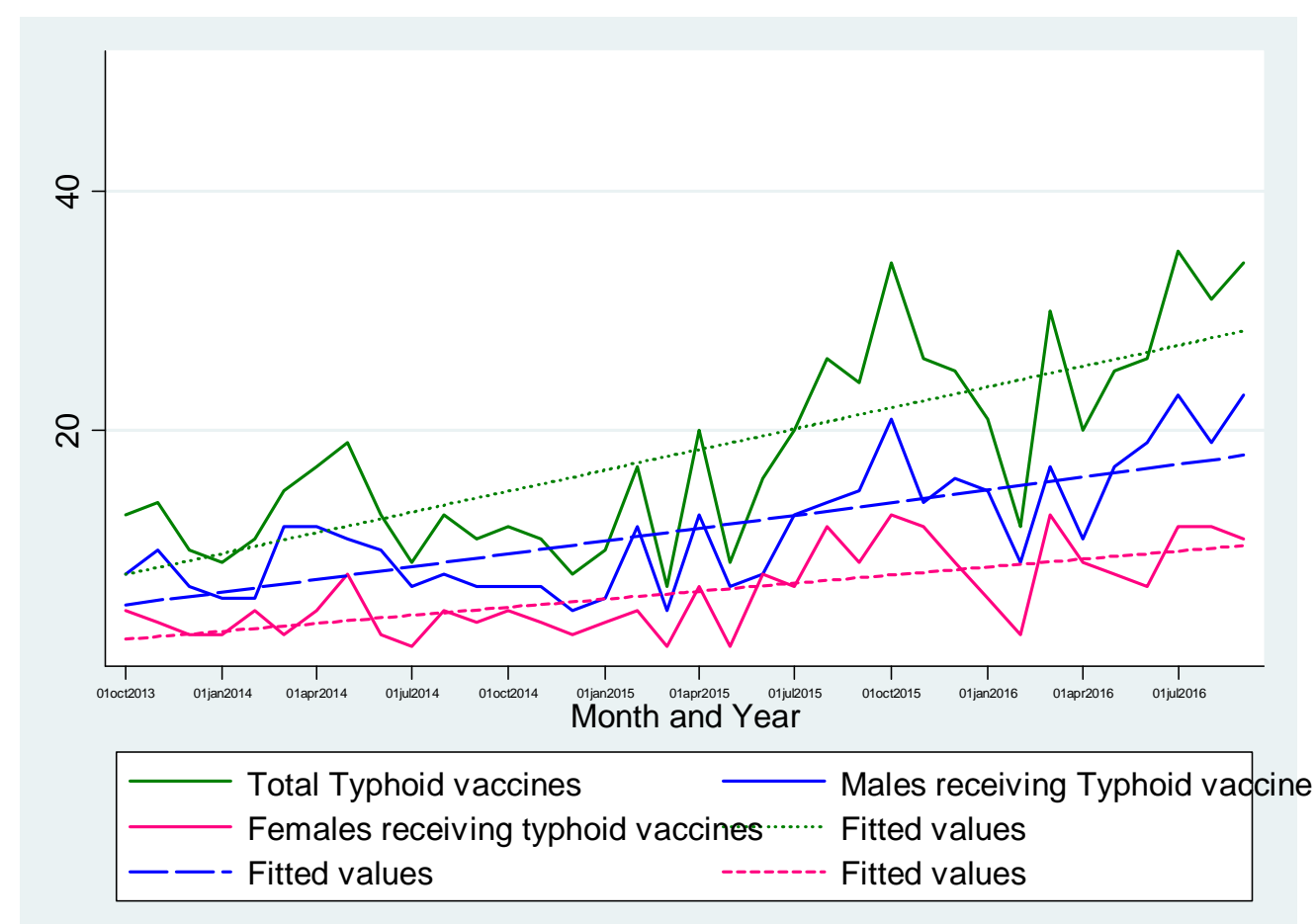

Fig 6: Trend of Varicella vaccines utilized at the clinic from 2013 to 2016

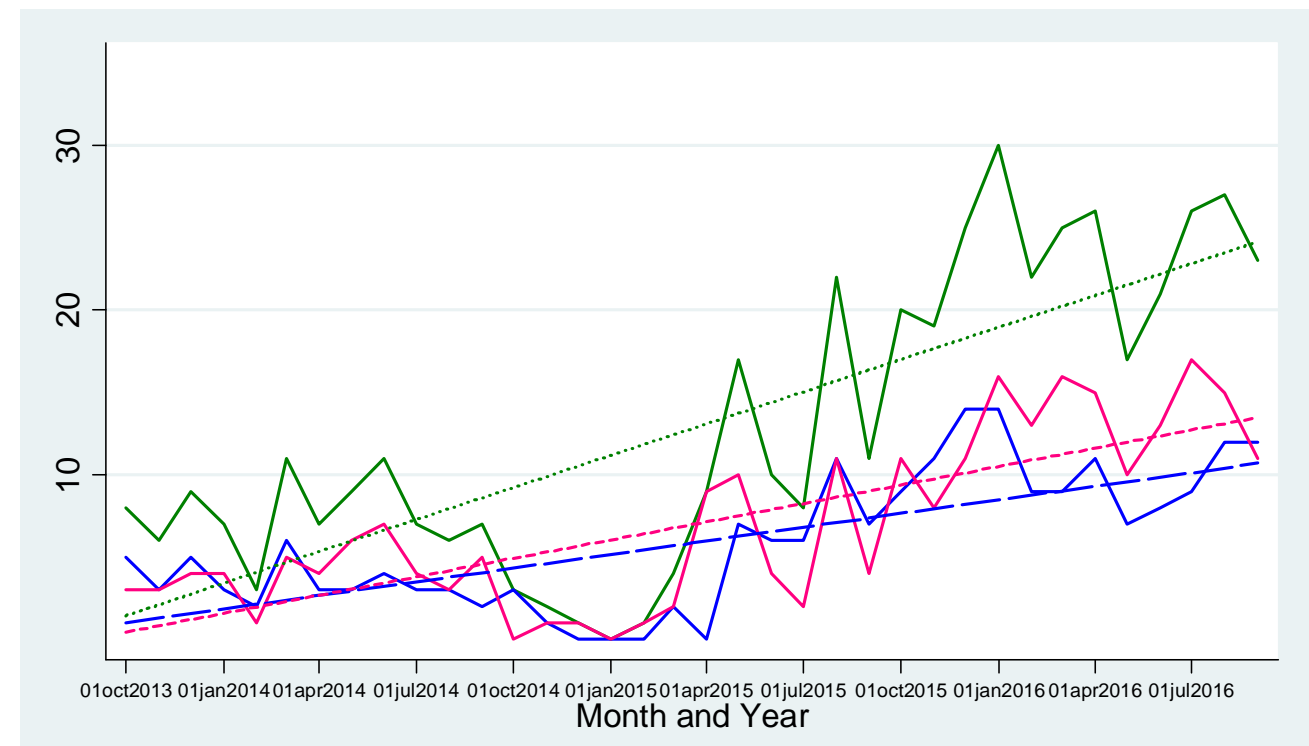

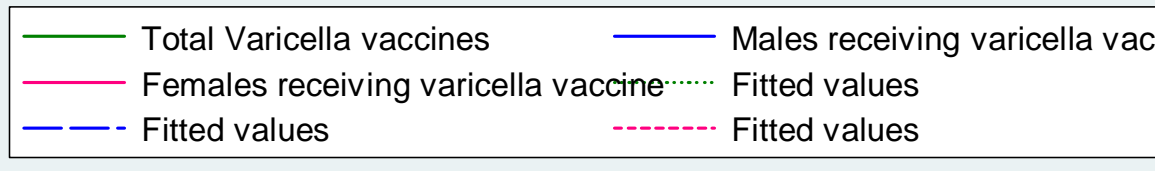


medRxiv preprint doi: https://doi.org/10.1101/2020.05.17.20072173; this version posted May 20, 2020. The copyright holder for this preprint (which was not certified by peer review) is the author/funder, who has granted medRxiv a license to display the preprint in perpetuity.

It is made available under a CC-BY-ND 4.0 International license .

Fig 7: Trend of Hepatitis A vaccines utilized at the clinic from 2013 to 2016

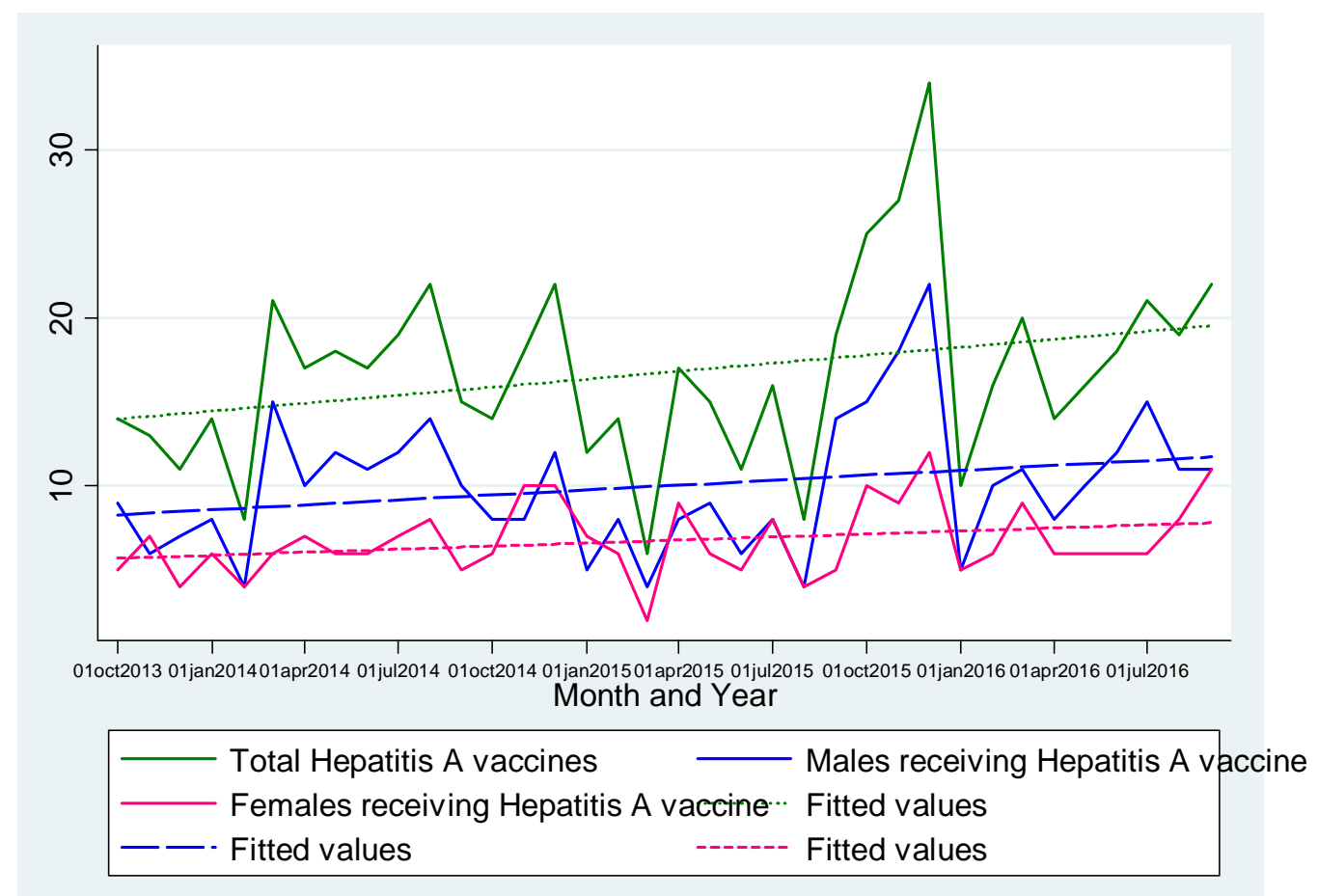

Fig 8: Total MMR vaccines utilized at the clinic from 2013 to 2016

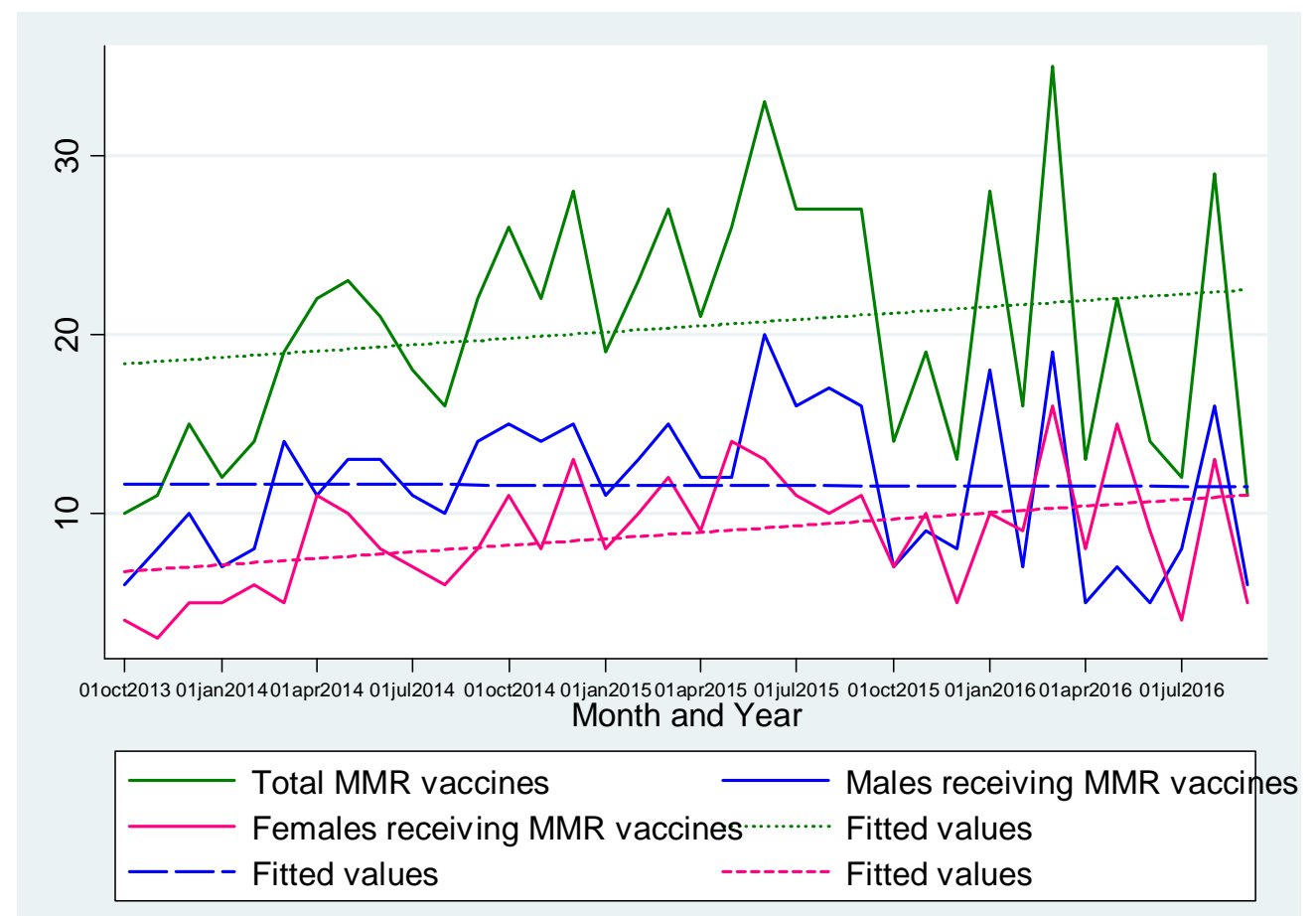


medRxiv preprint doi: https://doi.org/10.1101/2020.05.17.20072173; this version posted May 20, 2020. The copyright holder for this preprint (which was not certified by peer review) is the author/funder, who has granted medRxiv a license to display the preprint in perpetuity.

It is made available under a CC-BY-ND 4.0 International license .

Fig 9: Total Measles vaccines utilized at the clinic from 2013 to 2016

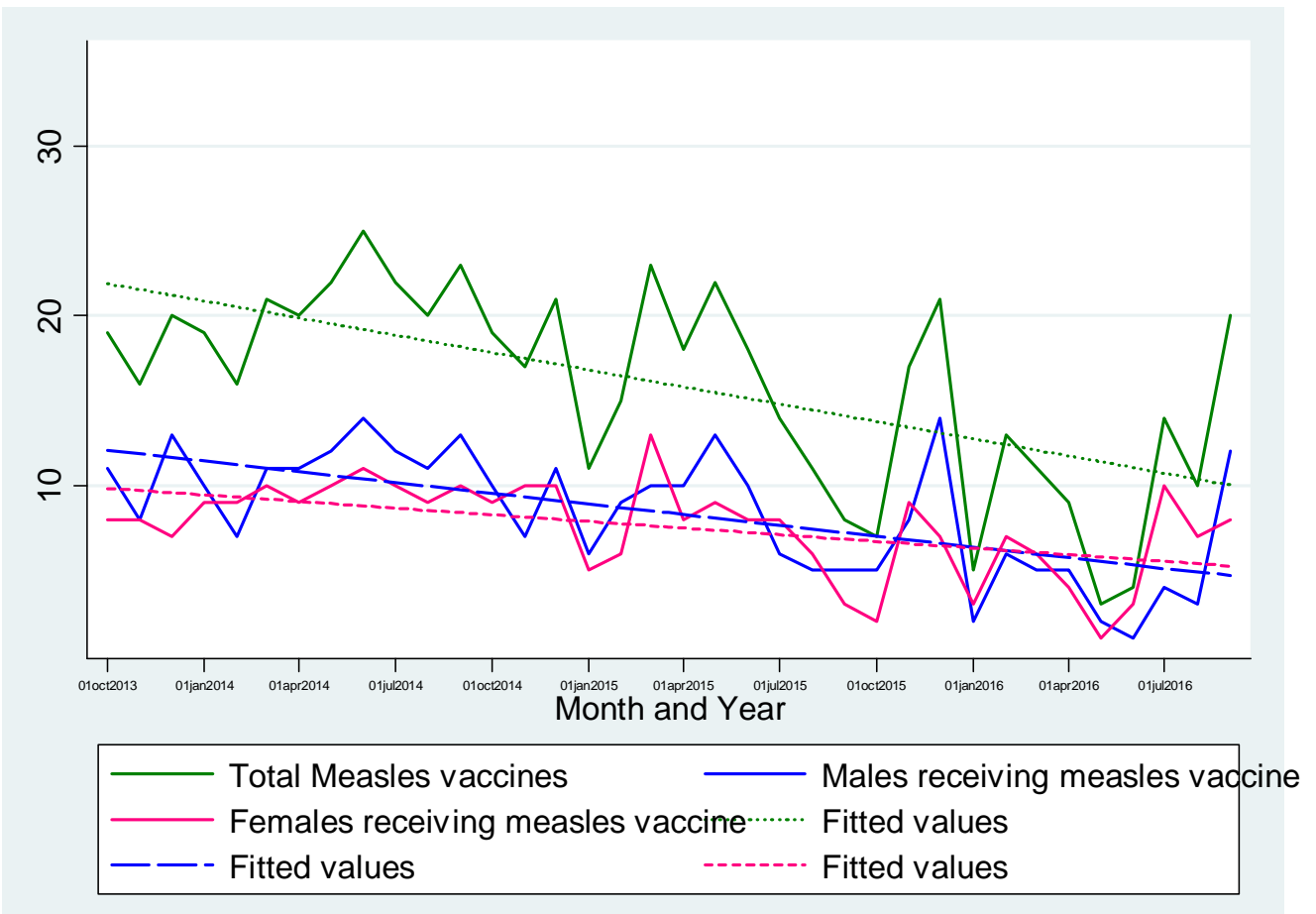

